\title{
Vulvar Cancer TNM Finding v8
}

National Cancer Institute

\section{Source}

National Cancer Institute. Vulvar Cancer TNM Finding v8. NCI Thesaurus. Code C139590.

A finding about one or more characteristics of vulvar cancer, following the rules of the

TNM AJCC v8 classification system. This classification system applies to all carcinomas of the vulva. Melanoma of the vulva is staged according to the classification for melanoma of the skin. (from AJCC 8th Ed.) 